\title{
$\mathrm{MBR}$ 유출수 재활용을 위한 RO 막분리 공정에 대한 연구
}

\author{
윤현수 ${ }^{2}$, 김종수 ${ }^{*}$ \\ ${ }^{1}$ 선문대학교 토목공학과, ${ }^{2}$ (주)지에스택
}

\section{Application of RO Membrane Process for Reuse of MBR Effluent}

\author{
Hyun-Soo Yoon ${ }^{2}$ and Jong-Soo Kim $^{1 *}$ \\ ${ }^{1}$ Department of Civil Engineering Sunmoon University, ${ }^{2}$ Green Solution Technology
}

요 약 S전자에서 발생되는 유기성 산업폐수의 생물학적 처리인 $\mathrm{MBR}$ 공정의 유출수를 $\mathrm{LCD}$ 제조공정의 용수로 재사용하기 위하여 $32 \mathrm{~m}^{3} / \mathrm{d}$ 규모의 pilot-scale RO 막분리 공정을 구축하고 RO 막분리 공정의 운전압력과 투과유량 에 따른 막간차압 및 $\mathrm{CIP}$ 주기 그리고 TOC와 전기전도도의 용질분리에 대한 영향을 분석하였다. MBR 공정의 유출 수는 일반적인 처리수 재사용 수질기준을 만족하나 $\mathrm{LCD}$ 제조공정의 $\mathrm{S}$ 전자 자체 재사용 용수 수질기준인 $\mathrm{TOC}<1 \mathrm{mg} / \mathrm{L}$ 와 전기전도도<100 $\mu \mathrm{S} / \mathrm{cm}$ 를 만족하지 못하므로 후속 처리가 불가피하다. RO 막분리 공정의 회수율을 $85 \%$ 로 일정하게 유지한 상태에서 투과유량을 $12.5 \mathrm{LMH}$ 에서 $22.0 \mathrm{LMH}$ 로 증가시키면서 운전한 결과 모든 투과유량 에서 RO 투과수는 자체 재활용 용수 수질기준을 만족하였다. 그러나 RO 막오염에 의한 막간차압이 상승되어 CIP 주기는 투과유량이 증가되면 짧아지는 효과가 나타났다. RO 막분리 공정의 최적 운전인자는 회수율 $85 \%$ 에서 투과 유량 $16.5 \sim 18.5 \mathrm{LMH}$ 이었으며 운전압력은 $6.7 \sim 12.4 \mathrm{kgf} / \mathrm{cm}^{2}$, CIP 주기는 투과생산량/운전비에 적절한 20 일 25일로 나타났다.

\begin{abstract}
Reuse feasibility of MBR effluent of S Electronic Company's organic wastewater as a LCD process water was investigated by a $32 \mathrm{~m} / \mathrm{d}$ pilot-scale RO membrane process. The effects of operating pressure and permeate flux at constant $85 \%$ recovery of RO membrane process using MBR effluent were analyzed for transmembrane pressure and period for CIP by membrane fouling as well as rejection of TOC and conductivity. MBR effluent requires additional treatment to meet the LCD process water quality criteria of $\mathrm{TOC}<1 \mathrm{mg} / \mathrm{L}$ and conductivity $<100 \mu \mathrm{S} / \mathrm{cm}$ which is stringent as compared with those of conventional reuse water quality criteria. The RO process operated at $85 \%$ recovery with stepwise increasing of permeate fluxes from 12.5 LMH to 22.0 LMH was able to meet LCD process water quality criteria. However, the transmembrane pressure increased and the period of CIP decreased as increasing permeability fluxes due to fouling of RO membrane. The optimum operational conditions of RO membrane process were permeate fluxes of $16.5 \sim 18.5$ LMH with operating pressure of $6.7 \sim 12.4 \mathrm{kgf} / \mathrm{cm}^{2}$ and CIP period of $20 \sim 25$ days at constant $85 \%$ recovery.
\end{abstract}

Key Words : Reuse of MBR effluent, RO Process, Operating Pressure, Permeate Flux, Transmembrane Pressure, Solute Separation

\section{1. 서론}

산업의 발달과 인구의 도시집중, 산업폐수와 생활하수 에 의한 수질오염은 수자원 관리에 심각한 문제로 떠오 르고 있다. 우리나라의 수자원장기종합계획(2006 2020) 에 따르면 2003년 기준 1 인당 가용수자원은 $1,512 \mathrm{~m}^{3}$ 으
로 물 스트레스 국가로 분류되고 있으며 현재 추세의 물 사용량이 증가되면 물 부족사태의 발생은 예상이 아닌 현실로 그 대책이 시급하지 않을 수 없다[1].

물 부족 사태의 해결을 위해 새로운 용수공급원의 개 발이 필요하며 최근 시도되고 있는 방법은 (1) 하폐수의 재사용, (2) 우수의 활용, 그리고 (3) 해수담수화가 있다.

*교신저자 : 김종수(jskim@sunmoon.ac.kr)

접수일 10 년 02 월 12 일수정일 10 년 04 월 07 일 게재확정일 10 년 04 월 09 일 
이중 하-폐수 처리수의 재사용은 공학적 접근이 가능한 방법으로 환경부는 하폐수의 재사용에 대한 이용목적별 수질 권고기준안을 표 1과 같이 제시하고 있다.[2] 수질 권고기준안의 항목은 일반적인 활성슬러지 공정 혹은 영 양염류 제거를 위한 고도처리를 연계한 활성슬러지 공정 에 의하여도 만족될 수 있으나 보다 더 안정적이며 처리 효율이 높은 공정이 요구되기도 한다. 최근 개발되어 실 용화되기 시작한 생물학적 처리에 MF(microfiltration) 혹 은 UF(ultrafiltration)를 장착한 MBR (membrane bioreactor) 공정이 시도되고 있으며 처리수 재사용을 위 한 수질 권고 기준안을 만족하는 것으로 나타나고 있다. 그러나 공업용수로 재사용 하는 경우 해당 산업체는 공 정 특성상 자체적으로 수립된 보다 엄격한 수질기준을 요구하며 이를 만족하기 위하여 $\mathrm{MBR}$ 공정에 역삼투 (RO, reverse osmosis)를 연계한 공법이 적용되고 있다. $\mathrm{S}$ 전자의 경우 $\mathrm{LCD}$ 제조공정의 공업용수로 재사용을 위한 자체 수질 기준으로 $\mathrm{TOC}<1 \mathrm{mg} / \mathrm{L}$ 그리고 전기전도도 $<100 \mu \mathrm{S} / \mathrm{cm}$ 를 적용하고 있다.

$\mathrm{RO}$ 막의 수투과도와 용질분리에 대한 이론은 RO 막 은 다공성이며 용매인 물이 용질보다 선택적으로 막표면 에 수착(sorption)되고 압력에 의하여 세공을 확산, 투과 함으로서 용질이 분리된다는 preferential sorptioncapillary flow mechanism[3]에 근거하고 있다. 이 이론에 의하면 RO 막에는 적정 수투과도와 용질분리를 만족시 키는 임계 세공직경이 존재하며 세공직경이 작으면 용질 분리 효율은 증가되나 수투과도는 감소하고 세공직경이 크면 분자량이 작은 용질 중 일부는 세공을 투과하게 되 어 용질분리 효율은 감소하나 수투과도는 증가하게 된다. $\mathrm{RO}$ 막오염은 막표면 혹은 막세공에 이물질의 축적으로 인한 일반적인 수투과도 감소현상을 통칭하여 정의되고 있다. $\mathrm{RO}$ 를 이용한 하-폐수의 재활용이나 해수담수화의 연구에서 막오염에 의한 운전압력의 상승과 CIP(clean in place) 주기의 필요성 그리고 수투과도의 감소는 막분리 공정의 실용화에 있어서 경제성과 관련하여 가장 큰 걸 림돌로 작용한다.[4-9] 따라서 RO 막분리 공정에서 운전 인자인 운전압력에 의한 수투과도, 용질분리, 막오염에 대한 영향을 분석한다는 것은 공정의 최적 운전조건 확 립에 필수적이다.

본 연구는 $\mathrm{S}$ 전자에서 발생되는 유기성 산업폐수를 처 리하는 MBR 공정의 유출수를 $\mathrm{LCD}$ 제조공정의 용수로 재사용하기 위하여 pilot-scale RO 막분리 공정을 구성하 고 $\mathrm{MBR}$ 공정 유출수를 이용한 RO 막분리 공정에서 운 전압력과 투과유량에 따른 막오염에 의한 막간차압과 $\mathrm{CIP}$ 주기 그리고 TOC와 전기전도도의 용질분리 효율의 영향을 분석하였다. 이러한 연구 결과는 MBR-RO system
의 처리수가 자체 $\mathrm{LCD}$ 공정의 공업용수 재사용 수질기 준을 만족할 수 있는 RO 막분리 공정의 운전조건을 제시 하고 full-scale MBR-RO system을 설계, 구축 및 운전 하 는데 기초자료로 활용될 것이다.

[표 1] 환경부 처리수 재사용 수질권고 기준

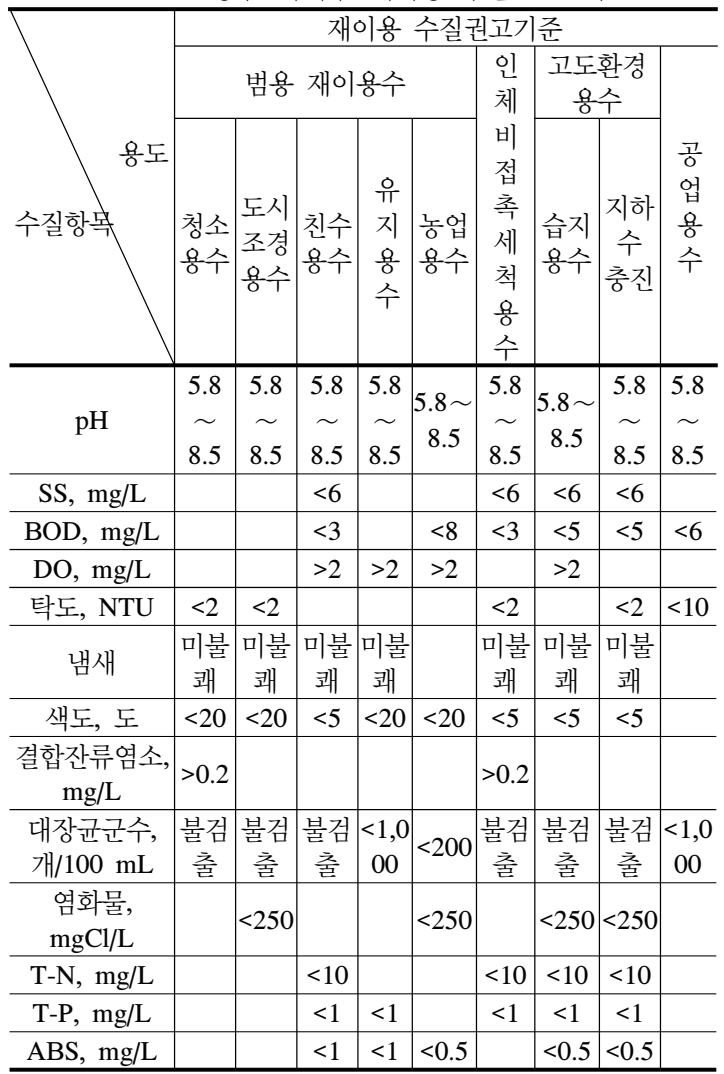

\section{2. 실험장치 및 방법}

\section{1 $\mathrm{MBR}$ 공정의 구성과 운전}

$\mathrm{S}$ 전자 유기폐수의 생물학적 처리인 $\mathrm{MBR}$ 공정 유출수 를 재사용하기 위한 후속 RO 막분리 공정에 대한 연구는 $\mathrm{MBR}$ 공정의 운전 결과에 영향을 받으므로 먼저 $\mathrm{MBR}$ 공정에 대하여 기술한다. MBR 공정은 용량 $50 \mathrm{~m}^{3} / \mathrm{day}$ 의 pilot-scale 규모로 그림 1과 같이 제작되었다. 유입수는 $\mathrm{pH}$ 조정조를 거쳐 탈질을 위한 무산소조(anoxic), 유기물 질의 제거와 질산화를 위한 포기조(oxic), 그리고 침지형 UF 막이 장착된 막 운전조(MOS, membrane operating system)로 구성되었다.

$\mathrm{MBR}$ 공정에 사용된 유입수 특성은 표 2에 요약되었 
다. $\mathrm{BOD}$ 와 $\mathrm{COD}_{\mathrm{Cr}}$ 는 각각 평균 $1,597 \mathrm{mg} / \mathrm{L}$, 평균 2,494 $\mathrm{mg} / \mathrm{L}$ 이며 $\mathrm{COD}_{\mathrm{Cr}} / \mathrm{BOD}$ 비는 일반적인 하수의 1.72 보다 낮은 1.54 로 나타났다. 유기폐수는 미생물의 성장에 필요 한 유기물에 대한 영양염류의 적정 비인 COD:N:P $=100: 5: 1$ 에 비교하여 낮은 질소와 인 함유량을 보이므로 질소 $\left(\mathrm{NH}_{4} \mathrm{HCO}_{3}\right)$ 와 인 $\left(\mathrm{H}_{3} \mathrm{PO}_{4}\right)$ 을 첨가하였다. 유입수의 $\mathrm{pH}$ 는 $\mathrm{NaOH}$ 혹은 $\mathrm{HCl}$ 에 의하여 $\mathrm{pH}$ 6 8로 조정하였다. 유입수에 함유된 오염물질 중 $\mathrm{MBR}$ 공정의 $\mathrm{UF}$ 막과 후 속 $\mathrm{RO}$ 막에 영향을 줄 수 있는 무기물질은 $\mathrm{Ca}^{2+}, \mathrm{Ba}^{2+}$, $\mathrm{Mg}^{2+}, \mathrm{SiO}_{2}$ 등이며 그 평균 농도는 각각 $14.8 \mathrm{mg} / \mathrm{L}, 0.15$ $\mathrm{mg} / \mathrm{L}, 0.61 \mathrm{mg} / \mathrm{L}, 1.66 \mathrm{mg} / \mathrm{L}$ 로서 막에 영향을 줄 수 있는 범위에 있는 것은 아닌 것으로 사료된다.

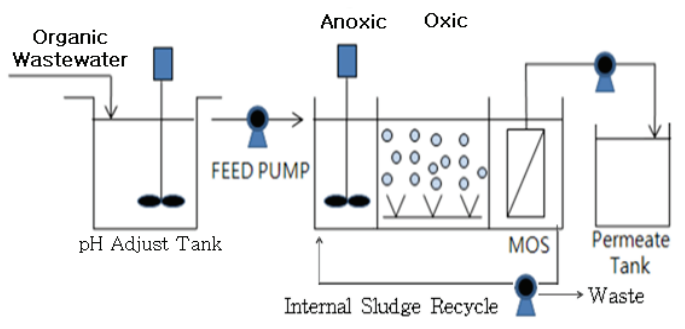

[그림 1] Pilot-scale MBR 공정의 개략도

[표 2] Pilot-scale MBR 공정의 유입수

\begin{tabular}{|c|c|c|}
\hline 항목 & 단위 & 평균 (범위) \\
\hline $\mathrm{pH}$ & - & $3.2(2.0 \sim 11.3)$ \\
\hline 전기전도도 & $\mu \mathrm{S} / \mathrm{cm}$ & $950(720 \sim 4,140)$ \\
\hline $\mathrm{COD}_{\mathrm{Cr}}$ & \multirow{5}{*}{$\mathrm{mg} / \mathrm{L}$} & $2,494(785 \sim 6,240)$ \\
\hline BOD & & $1,597(406 \sim 2,640)$ \\
\hline TOC & & $746(230 \sim 1,850)$ \\
\hline $\mathrm{T}-\mathrm{N}$ & & $66.0(13.0 \sim 125.0)$ \\
\hline T-P & & $3.6(0.3 \sim 9.1)$ \\
\hline $\mathrm{HCO}_{3-}^{-}$ & \multirow{3}{*}{$\begin{array}{l}\mathrm{mg} / \mathrm{L} \text { as } \\
\mathrm{CaCO}_{3}\end{array}$} & $2.1(0.0 \sim 12.9)$ \\
\hline $\mathrm{CO}_{3}{ }^{2-}$ & & $19.0(0.0 \sim 70.9)$ \\
\hline 경도 & & $37.0(10.0 \sim 75.0)$ \\
\hline $\mathrm{Ca}^{2+}$ & \multirow{4}{*}{$\mathrm{mg} / \mathrm{L}$} & $14.8(3.1 \sim 27.6)$ \\
\hline $\mathrm{Ba}^{2+}$ & & $0.15(0.06 \sim 0.41)$ \\
\hline $\mathrm{Mg}^{2+}$ & & $0.61(0.02 \sim 1.13)$ \\
\hline $\mathrm{SiO}_{2}$ & & $1.66(0.28 \sim 11.5)$ \\
\hline
\end{tabular}

MBR 공정의 생물반응조인 무산소조와 포기조의 유기 물 부하율(OLR, organic loading rate)은 1.8(1.0 3.3) $\mathrm{kgBOD} / \mathrm{m}^{3}-\mathrm{d}$ 그리고 유입유량을 조정하여 $\mathrm{F} / \mathrm{M}$ 비를 $0.41(0.17 \sim 0.82) \mathrm{kgBOD} / \mathrm{kgMLSS}$ 로 운전하였다. 생물반
응조의 SRT 30일 기준으로 내부반송과 폐기슬러지 유량 으로 조절하였으며 이에 따른 생물반응조 MLSS는 8,000 $\sim 10,000 \mathrm{mg} / \mathrm{L}$ 로 유지되었으며 HRT는 평균 22시간으로 운전되었다. 슬러지 내부반송은 $\operatorname{MOS}$ 조 내에서 유입유량 대비 평균 5 배로 내부반송 하였으며 일부 슬러지는 폐기 하였다. MBR 공정에 장착된 UF 막은 외국에서 제작된 침지형 중공사막으로 14 분 운전하고 30 초 동안 back pulse에 의한 역세척을 하는 방식으로 운전되었다. MOS 조의 MLSS는 무산소조과 포기조의 생물반응조보다 높 은 $10,000 \sim 12,000 \mathrm{mg} / \mathrm{L}$ 로 유지되었고, UF막의 투과유 량은 16 20 LMH $\left(\mathrm{L} / \mathrm{m}^{2}-\mathrm{hr}\right)$ 로 유지하였다.

\subsection{RO 막분리 공정의 구성과 운전}

$\mathrm{RO}$ 막분리 공정의 흐름도는 그림 2에 나타내었다. RO 막분리 공정은 용량 $32 \mathrm{~m}^{3} /$ day로 제작 되었다. $\mathrm{MBR}$ 공정 유출수는 유입펌프에 의하여 RO 막 보호를 위한 microfilter(MF, $5 \mu \mathrm{m}$ )를 거친 후 고압펌프에 의하여 1,2 , 3 단계로 구성된 $\mathrm{RO}$ 막분리 공정에 유입되었다. $\mathrm{RO}$ 막분 리 공정은 1 단, 2 단, 3 단 각각 $\mathrm{RO}$ 모듈을 3 개, 2 개, 1 개 병 렬로 연결되었고 각 단계의 농축수가 다음 단계로 유입되 는 단계적인 운전이 되도록 구성되었다. 3 단의 농축수는 자체 폐수종말처리시설 집수조로 이송 처리되었다.

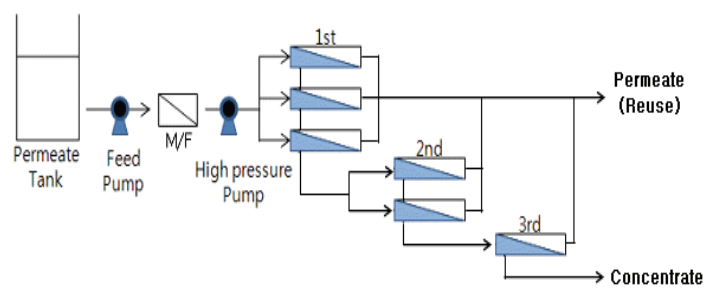

[그림 2] RO 막분리 공정의 흐름도

$\mathrm{RO}$ 막분리 공정에서 사용된 $\mathrm{RO}$ 막은 국내에서 제작 된 $\mathrm{S}$ 막으로 재질은 polyamide, 형태는 나권형이며 크기 는 직경 $6.25 \mathrm{~cm}$ 와 길이 $101.6 \mathrm{~cm}$ 로서 유효 막 면적은 $2.23 \mathrm{~m}^{2} / \mathrm{ea}$ 이다. 막 제조회사에서 추천하는 운전인자는 최대 운전압력 $15 \mathrm{kgf} / \mathrm{cm}^{2}$, 투과유량 $16.0 \mathrm{LMH}\left(\mathrm{L} / \mathrm{m}^{2}-\mathrm{hr}\right)$ 그리고 회수율 $85 \%$ 이다.

$\mathrm{RO}$ 막분리 공정의 운전은 막 제조회사가 추천하는 운 전조건인 회수율 $85 \%$ 그리고 운전압력 $15 \mathrm{kgf} / \mathrm{cm}^{2}$ 이하 를 유지하면서 운전압력의 조절에 따른 투과유량을 12.5 $22.0 \mathrm{LMH}$ 로 단계적으로 증가하면서 136일 동안 운전 하여 운전압력과 막간차압 그리고 용질분리 효율의 변화 를 분석하였다. 막간차압은 막오염에 의하여 발생되며 CIP는 주어진 recovery와 투과유량에 대하여 운전압력이 
$15 \%$ 로 증가한 경우에 실시하였다. RO 막의 CIP[10]는 유기 막오염의 경우 $\mathrm{NaOH}$ 에 의하여 $\mathrm{pH} 11$ 그리고 무기 막오염의 경우에는 $\mathrm{HCl}$ 에 의하여 $\mathrm{pH} 2$ 로 유지하여 세정 하였으며 온도는 $30^{\circ} \mathrm{C}$ 를 유지하였다.

$\mathrm{RO}$ 막분리 공정의 전 운전기간 동안 permeate tank 내 미생물의 성장을 억제하기 위하여 $\mathrm{NaOCl}$ 을 $4 \sim 5 \mathrm{mg} / \mathrm{L}$ 를 투입하였고 탈염소를 위하여 $\mathrm{NaHSO}_{3}$ 도 유입 전단부 (MF 후단)에 정량 투입하였다. 유입수의 $\mathrm{Ba}^{2+}$ 에 의한 막 내부에 황산바륨 스케일 형성을 방지하기 위하여 스케일 방지제(hyper disperse MDC-220)를 투입하였다.

\subsection{RO 막분리 공정의 성능분석}

$\mathrm{RO}$ 막분리 공정은 24 시간 연속으로 운전되기 때문에 운전인자는 주로 현장 감시에 의존하였고 용질분리 효율 은 시료를 채취하여 분석하는 방법을 병행하였다. 운전압 력과 막간차압은 압력게이지에 의하여 실시간 측정하였 다. 막간차압은 1 단의 RO 막 유입부분과 3 단의 RO 막 모듈의 농축수 부분에서 측정된 압력의 차이로 구하였다. 회수율은 유입유량 대비 투과수량의 비(\%)로 측정하였 다. $\mathrm{pH}$, 전기전도도 그리고 탁도는 portable 측정기에 의 하여 1 일 4회 이상 수시로 측정하였다. 용질분리 효율을 감시하기 위하여 RO 막분리 공정의 유입수 그리고 투과 수(1, 2, 3단 투과수의 혼합수)와 최종 RO 모듈의 농축수 에서 시료를 채취하였으며 $\mathrm{COD}_{\mathrm{Cr}}$ (dichromate $\mathrm{COD}$ ), $\mathrm{COD}_{\mathrm{Mn}}$ (permanganate $\mathrm{COD}$ ), 잔류염소 그리고 $\mathrm{SDI}(\mathrm{silt}$ density index)는 Standard Methods[11]에 준하여 분석하 였다. TOC(total organic carbon)는 TOC 분석기(GE Sievers 900, USA)에 의하여 on-line으로 분석하였다.

\section{3. 결과 및 고찰}

\subsection{Pilot-scale MBR 공정의 운전 특성}

$\mathrm{RO}$ 막분리 공정의 유입수는 $\mathrm{MBR}$ 공정의 처리에 직 접적인 영향을 받으므로 우선적으로 $\mathrm{MBR}$ 공정의 운전 이 안정적이며 정상상태를 유지되어야 한다. MBR 공정 은 약 4 개월의 식종 및 정상운전기간을 거친 후 RO 막 분리 공정과 결합되었다. 그러나 RO 막분리 공정의 운전 기간 동안 $\mathrm{MBR}$ 공정은 일부 불안정한 기간도 있었지만 $\mathrm{RO}$ 막분리 공정의 성능에는 크게 영향을 주지 못하였다.

$\mathrm{MBR}$ 공정을 운전한 결과 유출수 특성은 표 3에 요약 하였다. $\mathrm{MBR}$ 공정 유출수는 $\mathrm{COD}_{\mathrm{Cr}} 11.8(5.7$ 21.1) $\mathrm{mg} / \mathrm{L}$, TOC $5.6(4.1 \sim 26.0) \mathrm{mg} / \mathrm{L}$ 그리고 전기전도도 $650(102 \sim 1,500) \mu \mathrm{S} / \mathrm{cm}$ 의 범위에 있었다. 유기성 오염
물질의 처리 효율은 $\mathrm{COD}_{\mathrm{Cr}}$ 와 $\mathrm{TOC}$ 기준으로 평균 $98.5 \%$ 그리고 T-N은 57 94\%인 것으로 나타났다. MBR 공정 유출수에 함유된 오염물질 중 RO 막오염에 영향을 줄 수 있는 탁도는 MBR 공정의 초기에는 $2 \mathrm{NTU}$ 정도를 보였 으나 안정된 후 평균 $0.8 \mathrm{NTU}$ 를 유지되었고 $\mathrm{SDI}$ 는 평균 3.6으로 $\mathrm{RO}$ 막의 유입수 조건인 $\mathrm{SDI}<5$ 를 만족하였다. $\mathrm{MBR}$ 공정의 유출수는 하폐수 처리수의 일반적인 공업 용수로서 재사용 수질기준을 만족하고 있으나 $\mathrm{S}$ 전자 $\mathrm{LCD}$ 제조공정의 용수로 재사용을 위한 수질기준인 $\mathrm{TOC}<1 \mathrm{mg} / \mathrm{L}$ 과 전기전도도 $<100 \mu \mathrm{S} / \mathrm{cm}$ 을 만족하지 못 한다. 표 3 의 수질자료에 따르면 MBR 공정의 유출수는 재사용을 위한 RO 막분리 공정의 유입수로서 적용이 적 합하다고 판단된다.

[표 3] RO 막분리 공정의 유입수로 사용된 MBR 공정 유 출수 특성

\begin{tabular}{|c|c|c|}
\hline 항목 & 단위 & 평균 (범위) \\
\hline $\mathrm{pH}$ & - & $7.0(6.2 \sim 8.0)$ \\
\hline 전기전도도 & $\mu \mathrm{S} / \mathrm{cm}$ & $650(102 \sim 1,500)$ \\
\hline $\mathrm{COD}_{\mathrm{Cr}}$ & \multirow{8}{*}{$\mathrm{mg} / \mathrm{L}$} & $11.8(5.7 \sim 21.1)$ \\
\hline TOC & & $5.6(4.1 \sim 26.0)$ \\
\hline $\mathrm{T}-\mathrm{N}$ & & $8.8(0.4 \sim 65.0)$ \\
\hline T-P & & $0.34(0.3 \sim 7.3)$ \\
\hline $\mathrm{Ca}^{2+}$ & & $0.34(0.01 \sim 2.65)$ \\
\hline $\mathrm{Mg}^{2+}$ & & $0.03(0.01 \sim 0.27)$ \\
\hline $\mathrm{Ba}^{2+}$ & & $0.12(0.01 \sim 0.26)$ \\
\hline $\mathrm{SiO}_{2}$ & & $0.80(0.04 \sim 3.23)$ \\
\hline
\end{tabular}

\subsection{RO 막분리 공정의 운전 결과}

$\mathrm{RO}$ 막분리 공정은 회수율을 $85 \%$ 로 일정하게 유지하 면서 운전압력의 조절에 의하여 투과유량을 증가시키면 서 운전압력과 막간차압, 예상 CIP 주기 그리고 TOC와 전기전도도에 대한 용질분리 효율에 대한 영향을 비교 분석하였다. $\mathrm{RO}$ 막분리 공정의 운전은 1 단계 $12.5 \mathrm{LMH}$ 에서 29일간, 2단계 $16.5 \mathrm{LMH}$ 에서 55일간, 3단계 18.5 $\mathrm{LMH}$ 에서 37일간 그리고 4단계 $22.0 \mathrm{LMH}$ 에서 13일간 합계 136일 동안 운전하였다.

\subsection{1 투과유량의 운전압력과 막간차압에 대한 영향}

$\mathrm{RO}$ 막분리 공정의 전체 운전기간 동안 각 단계별 투 과유량의 운전압력과 막간차압에 대한 영향을 그림 3에 나타내었다. 1단계는 투과유량 $12.5 \mathrm{LMH}$ 에서 29 일 간 운전하였는데 운전압력은 $4.6 \mathrm{kgf} / \mathrm{cm}^{2}$ 에서 $5.2 \mathrm{kgf} / \mathrm{cm}^{2}$ 로 
그리고 막간차압은 $1.6 \mathrm{kgf} / \mathrm{cm}^{2}$ 에서 $2.2 \mathrm{kgf} / \mathrm{cm}^{2}$ 로 증가되 었다. 운전압력과 막간차압의 상승은 RO 막오염에의한 것으로 판단된다. 투과유량 $12.5 \mathrm{LMH}$ 는 막 제조회사의 추천 투과유량(16.5 LMH)보다 낮은 투과유량이므로 투 과유량적 측면에서 $100 \%$ 성능을 나타내고 있지 않다. 29 일간의 운전기간 동안 운전압력 상승은 $113 \%$ 정도로서 실제 CIP는 진행되지 않았지만 CIP 주기는 30 일 정도로 예측되었다.

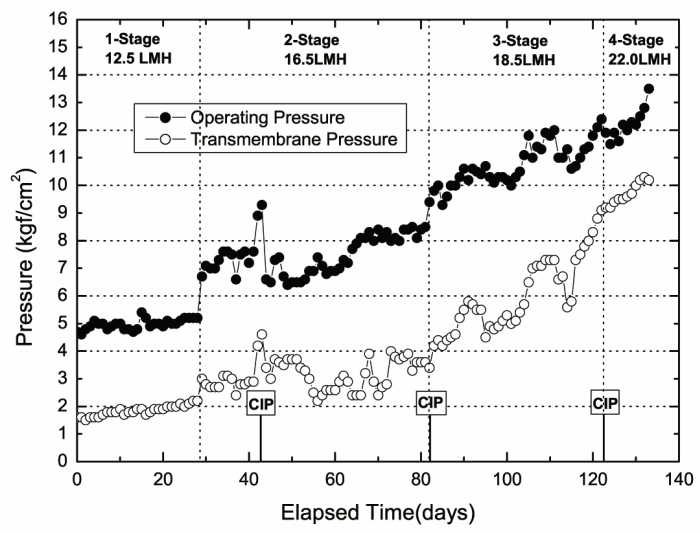

[그림 3] RO 막분리 공정에서 운전압력과 막간차압의 변화

투과유량 $12.5 \mathrm{LMH}$ 의 29일간 운전에서 운전압력과 막간차압의 증가가 미비하여 $\mathrm{CIP}$ 를 진행하지 않고 2단계 인 투과유량 $16.5 \mathrm{LMH}$ 로 운전 29일부터 55일간 운전하 였다. 2단계 초기 운전압력은 $6.7 \mathrm{kgf} / \mathrm{cm}^{2}$ 그리고 막간차 압은 $3.0 \mathrm{kgf} / \mathrm{cm}^{2}$ 이었으며 운전 30 40일 동안 그림 3 에 나타나듯이 운전압력과 막간차압은 각각 $7.5 \mathrm{kgf} / \mathrm{cm}^{2}$ 과 $3.0 \mathrm{kgf} / \mathrm{cm}^{2}$ 로 상승하며 일정하게 유지하였으나 그 후 1 2일 동안 운전압력은 $9.3 \mathrm{kgf} / \mathrm{cm}^{2}$, 막간차압은 4.6 $\mathrm{kgf} / \mathrm{cm}^{2}$ 까지 급격하게 상승하였다. 압력 상승의 원인은 MBR permeate tank에 직사광선에 의한 수온의 상승(3 $3^{\circ} \mathrm{C}$ )으로 미생물이 성장하여 막오염을 유발한 것으로 판 단되어 이에 대한 대책으로 운전 43 일에 $\mathrm{NaOCl}$ 을 투입 하여 미생물 증식을 억제시키고, $\mathrm{MF}$ 후단에 $\mathrm{NaHSO}_{3}$ 를 투입하여 잔류염소를 제거한 뒤 $\mathrm{CIP}$ 를 수행하였다. 그 결 과 운전압력은 $6.7 \mathrm{kgf} / \mathrm{cm}^{2}$ 그리고 막간차압은 3.0 $\mathrm{kgf} / \mathrm{cm}^{2}$ 로 감소되어 35 일 동안 연속운전이 가능하였다. CIP 이후 운전압력은 $8.5 \mathrm{kgf} / \mathrm{cm}^{2}$ 까지 상승하였고 CIP 주 기는 CIP 이후 운전압력인 $6.7 \mathrm{kgf} / \mathrm{cm}^{2}$ 의 $115 \%$ 되는 기간 인 25 일 정도로 예측되었다.

투과유량 $16.5 \mathrm{LMH}$ 의 55 일간 운전 후 $\mathrm{CIP}$ 를 진행하 고 3 단계인 투과유량 $18.5 \mathrm{LMH}$ 에서 운전 85 일부터 37일
간 운전하였다. 운전압력은 $9.8 \mathrm{kgf} / \mathrm{cm}^{2}$ 에서 $12.4 \mathrm{kgf} / \mathrm{cm}^{2}$ 로 그리고 막간차압은 $4.2 \mathrm{kgf} / \mathrm{cm}^{2}$ 이에서 $8.8 \mathrm{kgf} / \mathrm{cm}^{2}$ 로 지속적으로 상승하였다. 그림 3 에 나타난바와 같이 운전 115 일 116일에 운전압력과 막간차압이 급격히 하강하 였다. 원인은 2 단의 RO 모듈 한 개에서 pressure vessel의 brine seal과 U-cup의 손실을 가져와 유입유량의 일부분 이 모듈 밖으로 우회, 통과하였기 때문이고 문제의 RO 막을 교체한 결과 운전압력과 막간차압은 정상적으로 회 복되었다. CIP 주기는 투과유량 $18.5 \mathrm{LMH}$ 의 초기 운전 압력인 $9.8 \mathrm{kgf} / \mathrm{cm}^{2}$ 의 $115 \%$ 되는 기간인 20 일 정도로 예 측되었다.

4단계인 투과유량 $22.0 \mathrm{LMH}$ 로 운전을 하기 전에 CIP 를 실시하고 한계 투과유량 시험을 운전 123 일부터 13 일 간 실시하였다. 투과유량 $22.0 \mathrm{LMH}$ 의 초기 운전압력은 $11.9 \mathrm{kgf} / \mathrm{cm}^{2}$ 그리고 막간차압은 $9.2 \mathrm{kgf} / \mathrm{cm}^{2}$ 이었다. 투 과유량 $22.0 \mathrm{LMH}$ 로 운전 $\mathrm{MH} 12$ 일 후 그림 3 과 같이 운 전압력은 $13.7 \mathrm{kgf} / \mathrm{cm}^{2}$ 그리고 막간차압은 $10.3 \mathrm{kgf} / \mathrm{cm}^{2}$ 로 이하여 지속적인 운전을 할 수 없었다. CIP 주기는 투 과유량 $22.0 \mathrm{LMH}$ 의 초기 운전압력인 $11.9 \mathrm{kgf} / \mathrm{cm}^{2}$ 의 $115 \%$ 되는 기간인 12 일 정도로 예측되었다.

\subsection{2 투과유량의 용질분리 효율에 대한 영향}

$\mathrm{RO}$ 막분리 공정의 전 운전기간 동안 $\mathrm{TOC}$ 와 전기전도 도의 용질분리에 대한 결과는 각각 그림 4 와 5에 나타내 었다. 투과유량 $12.5 \mathrm{LMH}$ 의 1단계 운전에서 $\mathrm{RO}$ 막분리 공정의 유입수 $\mathrm{TOC}$ 는 초기 운전기간에 $25.6 \mathrm{mg} / \mathrm{L}$ 로 상 승하였으나 이후 $15 \mathrm{mg} / \mathrm{L}$ 범위로 안정되었다. 운전기간 동안 TOC는 유입수 $15.6(12.0 \sim 25.6) \mathrm{mg} / \mathrm{L}$ 에서 투과수 $0.171(0.092 \sim 0.42) \mathrm{mg} / \mathrm{L}$ 로 평균 $98.9 \%$ 그리고 전기전도 도는 유입수 794(725 947) $\mu \mathrm{S} / \mathrm{cm}$ 로서 투과수 20.6(14.1 30.0) $\mu \mathrm{S} / \mathrm{cm}$ 로 평균 $97.4 \%$ 의 제거효율이 각각 유지되 었다. 투과수의 $\mathrm{TOC}$ 와 전기전도도로 볼 때 자체 공업용 수 수질기준을 만족하였지만 낮은 투과유량으로 인하여 성능을 $100 \%$ 로 발휘하지 못함으로 인하여 투과생산량이 적어지는 결과를 초래하였다.

투과유량 $16.5 \mathrm{LMH}$ 의 2단계 운전기간 동안 $\mathrm{TOC}$ 는 유입수 7.8(4.4 22.0) $\mathrm{mg} / \mathrm{L}$ 에서 투과수 0.225(0.110 $0.657) \mathrm{mg} / \mathrm{L}$ 으로 평균 $97.1 \%$ 그리고 전기전도도는 유입 수 1,045(774 1,530) $\mu \mathrm{S} / \mathrm{cm}$ 에서 투과수 45.8(24.0 76.0) $\mu \mathrm{S} / \mathrm{cm}$ 로 평균 $95.5 \%$ 의 제거효율이 각각 유지되었 다. 투과유량 $18.5 \mathrm{LMH}$ 의 3 단계 운전기간 동안 $\mathrm{TOC}$ 는 유입수 9.7(4.0 25.6) $\mathrm{mg} / \mathrm{L}$ 에서 투과수 0.161(0.069 $0.402) \mathrm{mg} / \mathrm{L}$ 으로 평균 $98.3 \%$ 그리고 전기전도도는 유입 수 950(743 1,163) $\mu \mathrm{S} / \mathrm{cm}$ 에서 투과수 29.3(12.2 57.4) $\mu \mathrm{S} / \mathrm{cm}$ 로 평균 $96.9 \%$ 의 제거효율이 각각 유지되었다. 투 
과유량 $22.0 \mathrm{LMH}$ 의 4단계 운전기간동안 $\mathrm{TOC}$ 는 유입수 $6.0(4.7 \sim 6.8) \mathrm{mg} / \mathrm{L}$ 에서 투과수 $0.159(0.080 \sim 0.290) \mathrm{mg} / \mathrm{L}$ 으로 평균 $97.7 \%$ 그리고 전기전도도는 유입수847(758 $1,035) \mu \mathrm{S} / \mathrm{cm}$ 에서 투과수 36.4(28.1 53.0) $\mu \mathrm{S} / \mathrm{cm}$ 로 평 균 $95.7 \%$ 의 제거효율이 각각 유지되었다.

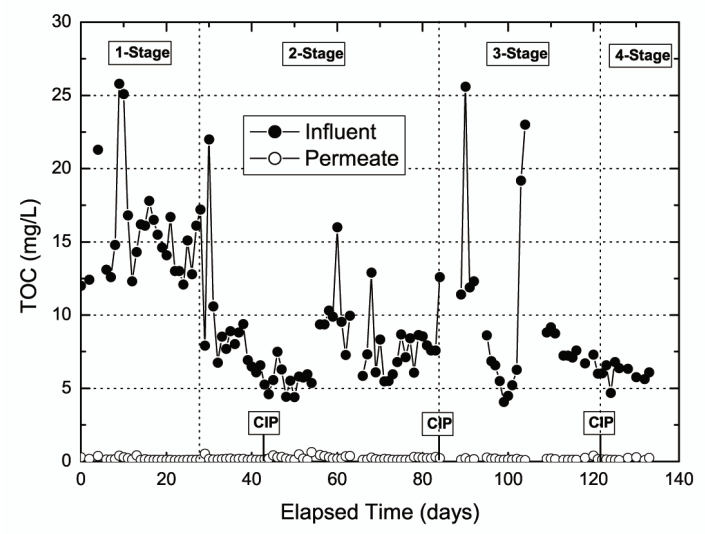

[그림 4] RO 막분리 공정에서 TOC 변화

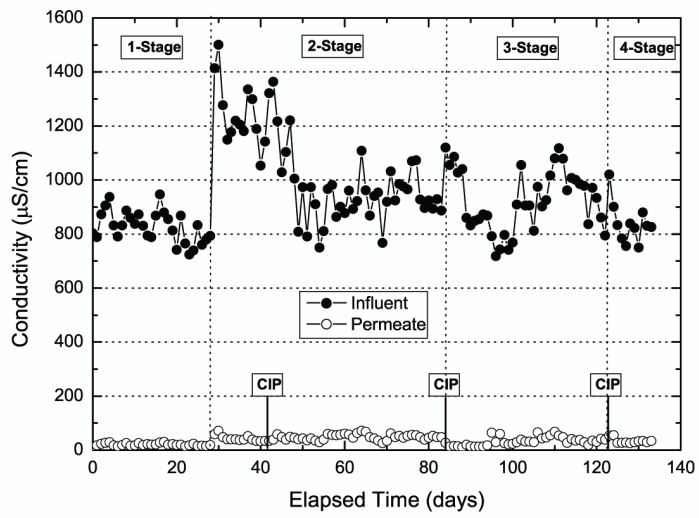

[그림 5] RO 막분리 공정에서 전기전도도 변화

\subsubsection{RO 막분리 공정의 운전결과에 대한 고찰}

$\mathrm{RO}$ 막분리 공정의 운전에서 회수율을 $85 \%$ 로 일정하 게 유지한 상태에서 투과유량을 $12.5 \mathrm{LMH}$ 에서 22.0 $\mathrm{LMH}$ 까지 증가시켜 운전한 결과 운전압력과 막간차압의 증가 그리고 예상되는 CIP 주기에 대한 결과를 Table 4 그리고 TOC와 conductivity의 용질제거 효율을 Table 5 에 각각 요약하였다.

투과유량 $12.5 \mathrm{LMH}$ 에서 $\mathrm{RO}$ 막분리 공정의 운전은

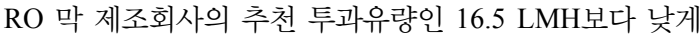
운전되었으므로 운전압력과 막간차압의 상승은 상대적으 로 낮았고 $\mathrm{CIP}$ 주기는 상대적으로 길어서 30 일 정도로
예측되었다. 투과수 수질로서 TOC는 0.171(0.092 0.42) $\mathrm{mg} / \mathrm{L}$ 그리고 전기전도도는 20.6(14.1 30.0) $\mu \mathrm{S} / \mathrm{cm}$ 을 유지하였다. 투과수 수질은 자체 수질기준인 $\mathrm{TOC}<1$ $\mathrm{mg} / \mathrm{L}$ 그리고 전기전도도 $<100 \mu \mathrm{S} / \mathrm{cm}$ 를 만족하지만 낮은 투과유량으로 인하여 성능을 $100 \%$ 로 발휘하지 못함으로 인하여 투과생산량이 적어지는 결과를 초래 할 것으로 판단된다. 투과유량 $16.5 \mathrm{LMH}$ 운전에서 운전압력은 $4.6 \mathrm{kgf} / \mathrm{cm}^{2} \sim 5.2 \mathrm{kgf} / \mathrm{cm}^{2}$ 그리고 막간차압은 $3.0 \mathrm{kgf} / \mathrm{cm}^{2}$ $\sim 4.1 \mathrm{kgf} / \mathrm{cm}^{2}$ 범위에 있었으며 CIP 주기는 25 일로 예측 되었다. 투과수 TOC는 $0.225(0.110 \sim 0.657) \mathrm{mg} / \mathrm{L}$ 그리고 전기전도도는 45.8(24.0 76.0) $\mu \mathrm{S} / \mathrm{cm}$ 유지하였으며 자 체 수질 기준을 만족하였다. 투과유량 $18.5 \mathrm{LMH}$ 운전에 서 운전압력은 $9.8 \mathrm{kgf} / \mathrm{cm}^{2} \sim 12.4 \mathrm{kgf} / \mathrm{cm}^{2}$ 그리고 막간차 압은 $4.2 \mathrm{kgf} / \mathrm{cm}^{2} \sim 8.8 \mathrm{kgf} / \mathrm{cm}^{2}$ 범위에 있었으며 CIP 주기 는 20일로 예측되었다. 투과수 TOC는 0.161(0.069 $0.402) \mathrm{mg} / \mathrm{L}$ 그리고 전기전도도는 29.3(12.2 57.4) $\mu$ $\mathrm{S} / \mathrm{cm}$ 로 역시 자체 수질기준을 만족하였다. 투과유량 16.5 $\mathrm{LMH}$ 와 $18.5 \mathrm{LMH}$ 에서의 운전은 운전압력과 막오염에 의한 막간차압도 막 제조회사의 추천 운전압력의 범위에 있으므로 $\mathrm{MBR}$ 유출수의 $\mathrm{LCD}$ 제조공정의 공업용수로 재사용을 위한 최적 운전조건이라고 판단된다.

[표 4] RO 막분리 공정에서 투과유량에 따른 운전압력, 막간차압과 CIP에 대한 영향

\begin{tabular}{c|c|c|c|c}
\hline $\begin{array}{c}\text { 투과 } \\
\text { 유량 }\end{array}$ & $\begin{array}{c}\text { 운전일수 } \\
\text { (day) }\end{array}$ & $\begin{array}{c}\text { 운전압력 } \\
\left(\mathrm{kgf} / \mathrm{cm}^{2}\right)\end{array}$ & $\begin{array}{c}\text { 막간차압 } \\
\left(\mathrm{kgf} / \mathrm{cm}^{2}\right)\end{array}$ & $\begin{array}{c}\text { CIP } \\
\text { 주기 } \\
\text { (day) }\end{array}$ \\
\hline 12.5 & 29 & $4.6 \sim 5.2$ & $1.6 \sim 2.2$ & 30 \\
\hline 16.5 & 55 & $6.7 \sim 8.5$ & $3.0 \sim 4.1$ & 25 \\
\hline 18.5 & 37 & $9.8 \sim 12.4$ & $4.2 \sim 8.8$ & 20 \\
\hline 22.0 & 13 & $11.9 \sim 13.7$ & $9.2 \sim 10.3$ & 12 \\
\hline
\end{tabular}

[표 5] RO 막분리 공정에서 투과유량에 따른 TOC와 전기전도도에 대한 영향

\begin{tabular}{c|c|c|c|c|c|c}
\hline \multirow{2}{*}{$\begin{array}{c}\text { 투과 } \\
\text { 유량 }\end{array}$} & \multicolumn{3}{|c|}{ TOC (평균) } & \multicolumn{3}{|c}{ 전기전도도(폅군) } \\
$(\mathrm{mg} / \mathrm{L})$ & $\begin{array}{c}\text { 투과수 } \\
(\mathrm{mg} / \mathrm{L})\end{array}$ & $\begin{array}{c}\text { 제거율 } \\
\%)\end{array}$ & $\begin{array}{c}\text { 유입수 } \\
(\mu \mathrm{S} / \mathrm{c} \\
\mathrm{m})\end{array}$ & $\begin{array}{c}\text { 투과수 } \\
(\mu \mathrm{S} / \mathrm{cm})\end{array}$ & $\begin{array}{c}\text { 제거율 } \\
(\%)\end{array}$ \\
\hline 12.5 & 15.6 & 0.171 & 98.9 & 794 & 20.5 & 97.4 \\
\hline 16.5 & 7.8 & 0.225 & 97.1 & 1,045 & 45.8 & 95.5 \\
\hline 18.5 & 9.7 & 0.161 & 98.3 & 929 & 29.3 & 96.9 \\
\hline 22.0 & 7.0 & 0.159 & 97.7 & 838 & 36.4 & 95.7 \\
\hline
\end{tabular}

투과유량 $22.0 \mathrm{LMH}$ 로 한계 투과유량 시험을 13 일간 실시한 결과 운전압력은 막 제조회사의 추천 운전압력에 근접하면서 CIP 주기는 12 일으로 예측되어 지속적인 운 전을 할 수 없었다. 그러나 용질분리 효율을 보면 투과수 
TOC는 0.159(0.080 0.290) $\mathrm{mg} / \mathrm{L}$ 으로 평균 $97.7 \%$ 그리 고 전기전도도는 36.4(28.1 53.0) $\mu \mathrm{S} / \mathrm{cm}$ 로 평균 95.7\% 의 제거효율을 각각 유지하여 자체 수질기준을 만족하고 있으나 고압의 운전압력과 짧은 CIP 주기로 인하여 최적 운전조건에서 제외되었다.

\section{4. 결론}

$\mathrm{S}$ 전자 유기성 산업폐수를 LCD 제조공정의 용수로 재 사용하기 위하여 MBR에 RO막을 결합한 pilot-scale MBR-RO 시스템을 구성하고 MBR 유출수를 이용하여 $\mathrm{RO}$ 막분리 공정을 회수율을 $85 \%$ 로 일정하게 유지한 상 태에서 투과유량을 12.5 22.0 LMH로 운전하여 운전압 력과 막간차압 그리고 용질인 $\mathrm{TOC}$ 와 전기전도도의 제거 효율에 대한 영향을 연구한 결과 다음과 같은 결론을 얻 었다.

(1) MBR 유출수는 환경부 하폐수 처리수의 일반적인 재사용 수질기준을 만족하고 있으나 $\mathrm{S}$ 전자 $\mathrm{LCD}$ 제조공정의 공업용수로 재사용 수질기준인 $\mathrm{TOC}<1$ $\mathrm{mg} / \mathrm{L}$ 와 전기전도도 $<100 \mu \mathrm{S} / \mathrm{cm}$ 를 만족하지 못하 므로 후속처리에 의하여 재사용 수질기준을 만족 할 수 있도록 하여야 한다.

(2) MBR 공정의 유출수를 이용한 RO 막분리 공정에 서 운전압력과 막간차압은 투과유량이 증가에 따 라 증가하였고 투과유량별 CIP 주기는 $12.5 \mathrm{LMH}$ 에서 30일, $16.5 \mathrm{LMH}$ 에서 25일, $18.5 \mathrm{LMH}$ 에서 20 일 그리고 $22.0 \mathrm{LMH}$ 에서 12 일로 각각 산출되었 다.

(3) $\mathrm{RO}$ 막분리 공정에서 투과유량 $12.5 \mathrm{LMH} 22.0$ $\mathrm{LMH}$ 의 운전조건은 $\mathrm{MBR}$ 공정의 유출수를 $\mathrm{S}$ 전자 $\mathrm{LCD}$ 제조공정 용수로 재사용하는 수질기준인 $\mathrm{TOC}<1 \mathrm{mg} / \mathrm{L}$ 과 전기전도도 $100 \mu \mathrm{S} / \mathrm{cm}$ 를 만족하 였다.

(4) MBR 유출수를 이용하여 회수율을 $85 \%$ 로 일정하 게 유지한 상태에서 $\mathrm{RO}$ 막분리 공정의 최적 운전 조건은 운전압력 $6.7 \mathrm{kgf} / \mathrm{cm}^{2} \sim 12.4 \mathrm{kgf} / \mathrm{cm}^{2}$ 에 의 한 투과유량 $16.5 \mathrm{LMH} 18.5 \mathrm{LMH}$ 으로 막간차압 은 $3.0 \mathrm{kgf} / \mathrm{cm}^{2} \sim 8.8 \mathrm{kgf} / \mathrm{cm}^{2}$ 그리고 CIP 주기는 20 25일 이었다. 최적 운전조건에서 $\mathrm{RO}$ 투과수는 $\mathrm{S}$ 전자 $\mathrm{LCD}$ 제조공정 용수 재사용 수질기준인 $\mathrm{TOC}<1 \mathrm{mg} / \mathrm{L}$ 과 전기전도도 $100 \mu \mathrm{S} / \mathrm{cm}$ 를 만족하 였다.

\section{참고문헌}

[1] 국토해양부, "수자원장기종합계획 보고서", June, 2006.

[2] 환경부, "하수 처리수 재이용 가이드북", 환경부 고시 제2007-511호, 2007.

[3] Sourirajan, S. and Matsuura, T., "Reverse osmosis /ultrafiltration, Process Principles", National Research Council of Canada, Ottawa, Canada, 1985.

[4] 강신경, 전희동, 박영규, “역삼투시스템을 이용한 산 업폐수 재이용 기술의 실용화 연구", 대한환경공학회 지, 21(9), 1689-1697, 1999.

[5] Vrijenhoek, E.M., Hong, S., and Elimelech, M., "Influence of Membrane Surface Properties on Initial Rate of Colloidal Fouling of Reverse Osmosis and Nanofiltration Membranes", J. Memb. Sci., 188(1), 115-128, 2001.

[6] 정지연, 이진욱, 김성연, 김인수, "역삼투 해수담수화 공정내 바이오 필름 형성 미생물의 부착 및 고압내 성 특성”, 대한환경공학회지, 31(1), 51-57, 2009.

[7] 윤종섭, 김승현, 윤조희, 김건태, "역삼투 해수담수화 의 전처리용 정밀여과 공정의 운전성능 및 운전효율 에 영향을 미치는 인자", 대한환경공학회지, 26(4), 475-480, 2004.

[8] Ng, H.Y., Tay, K.G., Chua, S.C., and Seah, H., "Innovative Large-Diameter RO System for Water Reclamation and Seawater Desalination", Water Sci. \& Tech.:Water Supply-WSTWS, 8(1), 93-99, 2008.

[9] Manttari, M. and Nystrom, M., "Membrane Filtration for Tiertiary Treatment of Biologically Treated Effluent for the Pulp and Paper Industry, Water Sci., \& Tech., 55(6), 99-107, 2007.

[10] (주)새한 필터컴퍼니, 역삼투 분리막, pp 122 123, 2000.

[11] APHA, AWWA, WEF, "Standard Methods for the Examination of Water and Wastewater, 21st Eds., Washington, DC, USA, 2005. 


\section{김 종 수(Jong-Soo Kim)}

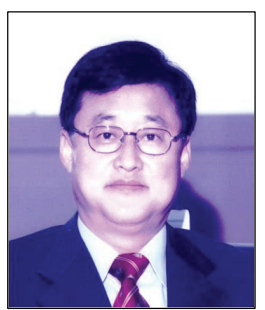

1983년 3월 : (미)Georgia Institute of Technology, 토목환경공학과 (공학석사)

- 1987년 3월 : (미)Georgia Institute of Technology, 토목환경공학과 (공학박사)

- 1987년 3월 1990년 12월 : (미)HazWaste Ind., Inc.

- 1991년 1월 1991년 12월 : (미)조지아공대연구소

- 1992년 1월 현재 : 선문대학교 환경공학과/토목공학 과 교수

<관심분야>

상하수도, 폐하수처리, 유기성폐자원의 에너지화, 막분리
윤 현 수(Hyun-Soo Yoon)

[정회원]

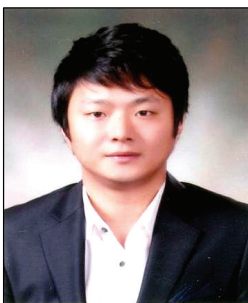

- 2006년 2월 : 선문대학교 환경공 학과 (공학사)

- 2009년 8월 : 선문대학교 대학원 환경공학과 (공학석사)

- 2005년 9월 2009년 12월 : (주)엔텍

- 2010년 1월 현재 : (주)지에스 텍

<관심분야>

생물학적 수처리, 막분리 공정 